\title{
Late Miocene Ostracoda from NW Libya
}

\author{
AHMED. A. EL-WAER \\ Geology Department, Hull University, Cottingham Road, Hull HU6 7RX
}

\begin{abstract}
Nine ostracod species from the Late Miocene Al Khums Formation (exposed $2 \mathrm{~km}$ north of Qabilat ash Shurfah, NW Libya) are described and illustrated in this paper. Of these, four species, namely Cytherella libyaensis, Actinocythereis spinosa, Keijella africana and Neomonoceratina miocaenica, are new; one was established by Doruk (1980), one by Moyes (1965) and the other three species are left under open nomenclature. These species support the macrofossil, foraminiferal and other ostracod (Innocenti \& Pertusati, 1984 and El-Waer, in press) evidence in suggesting a Late Miocene age.
\end{abstract}

\section{INTRODUCTION}

The present study deals with Ostracoda from the Late Miocene A1 Khums Formation exposed $2 \mathrm{~km}$ north of Qabilat ash Shurfah (see Fig. 1). The exposed section of the Formation measures approximately $14 \mathrm{~m}$, and varies in composition between marlstone, calcarinitic limestone and calcareous clay. Four samples were collected from the section (see Fig. 2) in 1983 by Mr. K. Sherif of the Industrial Research Centre, Tripoli, Libya. These beds are overlain by fluvio-aeolian deposits. The Miocene samples yielded a fairly rich and well preserved ostracod fauna (El-Waer, in press), containing Cytherella sp., Cytherella (Cytherella) vandenboldi Sissingh, 1972, Propontocypris sp., Loculicytheretta aff. miocaenica Szczechura, 1978, Mutilus carinatus Doruk, 1973, Loxoconcha sp., Loxoconcha (Palmoconcha) sp., Paracytheridea gharianensis sp. nov., Paracytheridea sp., Paijenborchellina punctata sp. nov., Neomonoceratina mouliana Sissingh, 1972, Neomonoceratina conulata sp. nov., Actinocythereis libyaensis sp. nov., Chrysocythere alkhumia sp. nov., Chrysocythere cataphracta muricata subsp. nov., Cistacythereis calamistrata Doruk, 1973, Cistacythereis qabilatshurafensis sp. nov., Falunia sicula Aruta, 1966, Ruggieria tetraptera tetraptera (Seguenza, 1897), Ruggieria miocaenica sp. nov., Keijella hodgii (Brady, 1866), Hermanites abundans sp. nov. and one genus left under open nomenclature.

The present work covers a number of important species which were discovered in examining further material. These are Cytherella libyaensis sp. nov., Propontocypris sp., Callistocythere sp., Actinocythereis spinosa sp. nov., Keijella africana sp. nov., Neomonoceratina miocaenica sp. nov., Loxoconcha sp., Paracytheridea inscita Doruk, 1980, and Carinovalva carinata (Moyes, 1965) from the same sequence. The occurrence at this stratigraphical level of two previously described species provides additional evidence for a Late Miocene age.
All figured specimens are deposited in the collections of the Geology Department, University of Hull, England.

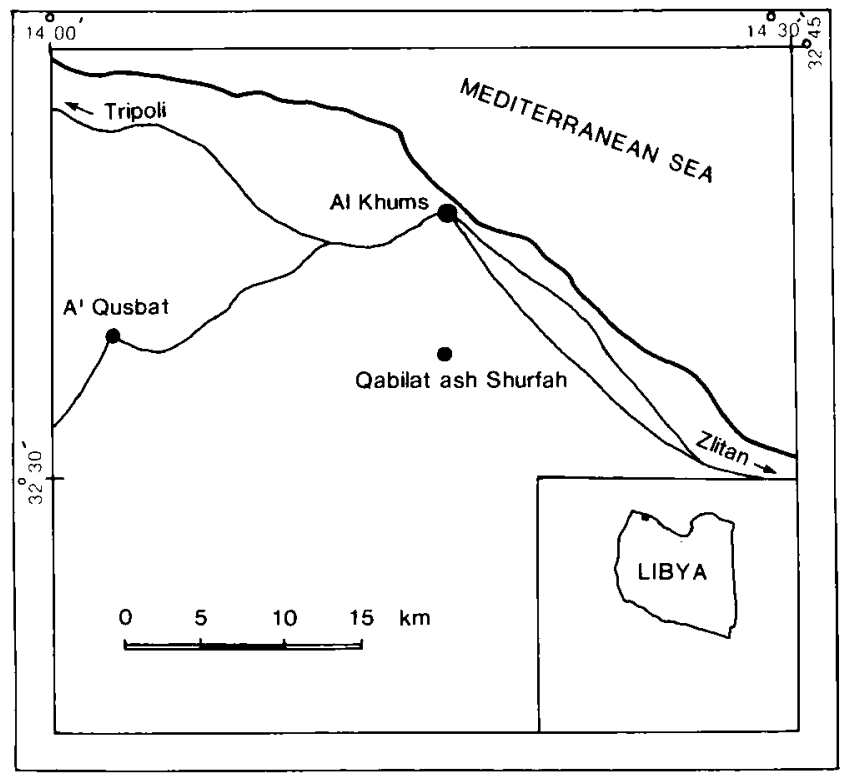

Fig. 1. The study area.

SYSTEMATIC DESCRIPTIONS

Subclass Ostracoda Latreille, 1806

Order Podocopida Muller, 1894

Suborder Platycopina Sars 1866

Family Cytherellidae Sars, 1866

Genus Cytherella Jones, 1849

Cytherella libyaensis sp. nov.

(Pl. 1, figs. 1-3)

Derivation of name. From its occurrence in Libya. Diagnosis. A species of the genus Cytherella characterised by its coarsely pitted surface. The location of the 
muscle scar area is indicated by a small, shallow depression.

Holotype. Male left valve, HU.317.T.3; PI. 1, fig. 3. Paratypes. Two specimens, HU.317.T.1,2; Pl. 1, figs. 1,2 and two right valves and one left valve (HU.317.T.24).

Type locality and horizon. $2 \mathrm{~km}$ north of Qabilat ash Shurfah, Late Miocene, sample 3.

Description. Carapace elongate to ovate in lateral view, with greatest height at the posterior margin. Dorsal margin straight, sloping gently to the anterior margin. Ventral margin slightly concave in the middle and curved upwards anteriorly. Posterior margin is rounded. The lateral surface is covered by coarse pits. The area of the muscle scar attachment is indicated by a small, shallow depression. The left valve is larger than the right. Sexual dimorphism is pronounced, the presumed males are more elongate and less high than the females. The internal features not visible.

Dimensions of figured specimens (in $\mu \mathrm{m}$ ) Length Height Paratype, male right valve. HU.317.T.1. $650 \quad 358$ Paratype, female right valve, HU.317.T.2. $613 \quad 373$ Holotype, male left valve, HU.317.T.3. 653360

Remarks. Cytherella libyaensis sp. nov. shows affinities with Cytherella (Cytherella) vandenboldi Sissingh, 1972, in its outline, but differs in having a straight. gently sloping dorsal margin, and a narrower anterior end.

Occurrence. Only at the type locality: sample 3 of the section $2 \mathrm{~km}$ north of Qabilat ash Shurfah.

Suborder Podocopina Sars, 1866

Superfamily Cypridacea Baird, 1845

Family Pontocyprididae Muller, 1894

Subfamily Pontocypridinae Muller, 1894

Genus Propontocypris Sylvester-Bradley, 1948

Propontocypris sp.

(Pl. 1, figs. 4-5)

Material. Three carapaces.
Description. In lateral view, carapace elongate to subtriangular, with greatest height nearly at the midlength. Anterior margin obliquely rounded, posterior end narrowly rounded and lower than the anterior end. Dorsal margin is broadly arched, highest anteriorly, where the anterodorsal margin slopes gently anteriorly and the posterodorsal posteriorly. Ventral margin is straight to slightly concave in the left valve. Lateral surface smooth to finely pitted. In dorsal view the carapace is elongate, compressed anteriorly and posteriorly and with the maximum width at the mid-length.

Dimensions of figured specimens (in $\mu \mathrm{m}$ ).

Female, carapace, HU.317.T.4. $\quad 600 \quad 325$

Male, carapace, HU.317.T.5. $625 \quad 310$

Remarks: This species is very similar to Propontocypris sp. El-Waer (in press), but the latter species differs in having a less arched dorsal margin and a more pointed posterior end than the present one. This species is represented only by closed carapaces and it has not been possible to ascertain the finer morphological details. It is placed in Propontocypris on the basis of the general shape.

Occurrence. $2 \mathrm{~km}$ north of Qabilat ash Shurfah, Late Miocene, sample 3.

Superfamily Cytheracea Baird, 1850

Family Leptocytheridae Hanai, 1957

Genus Callistocythere Ruggieri, 1953

Callistocythere $\mathrm{sp}$.

(Pl. 1, fig. 6)

Material. One left valve.

Description. Carapace elongate, subrectangular in laterial view, greatest height at the anterior cardinal angle. Anterior margin rounded, posterior margin obliquely rounded and lower than the anterior end. Dorsal margin slightly convex and sloping gently to anterior and posterior cardinal angles. Ventral margin straight. Ornamentation consists of a complex pattern of ridges and intervening fossae. Behind the sub-central tubercle

\section{Explanation of Plate 1}

Figs. 1-3. Cytherella libyaensis sp. nov.: fig. 1, paratype, male right valve, HU.317.T.1 ( $\times 61)$; fig. 2, paratype, female internal view. right valve, HU.317.T.2 ( $\times 61)$ : fig. 3 . holotype, male left valve. HU.317.T.3 $(\times 57)$.

Figs. 4, 5. Propontocypris sp.: fig. 4, female carapace from left, HU.317.T.4 $(\times 75)$; fig. 5, male carapace from right. HU.317.T.5 $(\times 75)$.

Fig. 6. Callistocythere sp., left valve, HU.317.T.6 $(\times 57)$.

Figs. 7-9. Actinocythereis spinosa sp. nov.: fig. 7. holotype, left valve. HU.317.T.7 ( $\times 60)$; fig. 8 , paratype, muscle scar pattern, HU.317.T.8; fig. 9, paratype, internal view, left valve, HU.317.T.8 $(\times 61)$.

Figs. 10, 11. Keijella africana sp. nov.: fig. 10. paratype. female carapace from right, HU.317.T.9 $(\times 70)$ : fig 11 , holotype, male carapace from right. HU.317.T. I $1(\times 68)$.

Fig. 12. Carinovalva carinata (Moyes, 1965). carapace. dorsal view. HU.317.T.11 $(\times 82)$. 


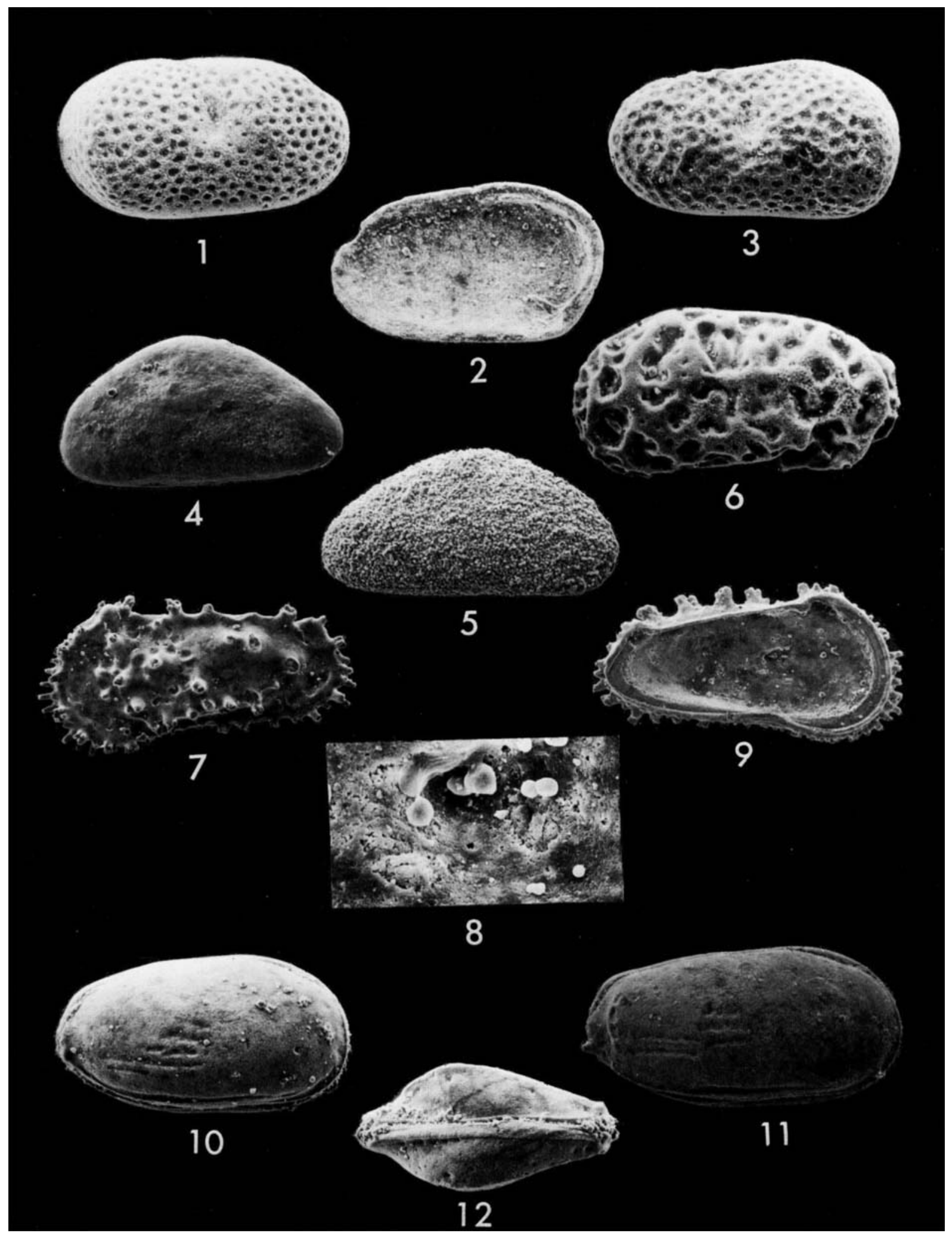






Fig. 2. The exposed section of the Al Khums Formation.

\section{Explanation of Plate 2}

Figs 1, 2 Carinovalva carinata (Moyes, 1965); fig. 1, male carapace from right, HU.317.T.12 ( $\times 79)$; fig. 2, female carapace from left, HU.317.T.13 $(\times 78)$.

Figs. 3-8 Neomonoceratina miocaenica sp. nov.: fig. 3, holotype, female left valve, HU.317.T.14 ( $\times 60)$; fig. 4 , paratype, female right valve, HU.317.T.15 $(\times 66)$; fig. 5, paratype, male carapace, dorsal view (specimen lost), HU.317.T.16 $(\times 67)$; fig 6, paratype, male right valve, HU.317.T.17 $(\times 65)$; fig. 7 , paratype, male right valve, HU.317.T.18 $(\times 65)$; fig. 8, paratype, male right valve, internal view, HU.317.T.19 $(\times 65)$.

Figs. 9-11. Loxoconcha sp.: fig. 9, female, carapace from left, HU.317.T.20 $(\times 70)$; fig. 10, female, carapace from right, HU.317.T.21 $(\times 68)$; fig. 11, male, carapace from right, HU.317.T.22 $(\times 69)$.

Fig. 12. Paracytheridea inscita Doruk, 1980, male right valve, HU.317.T.23 $(\times 87)$. 


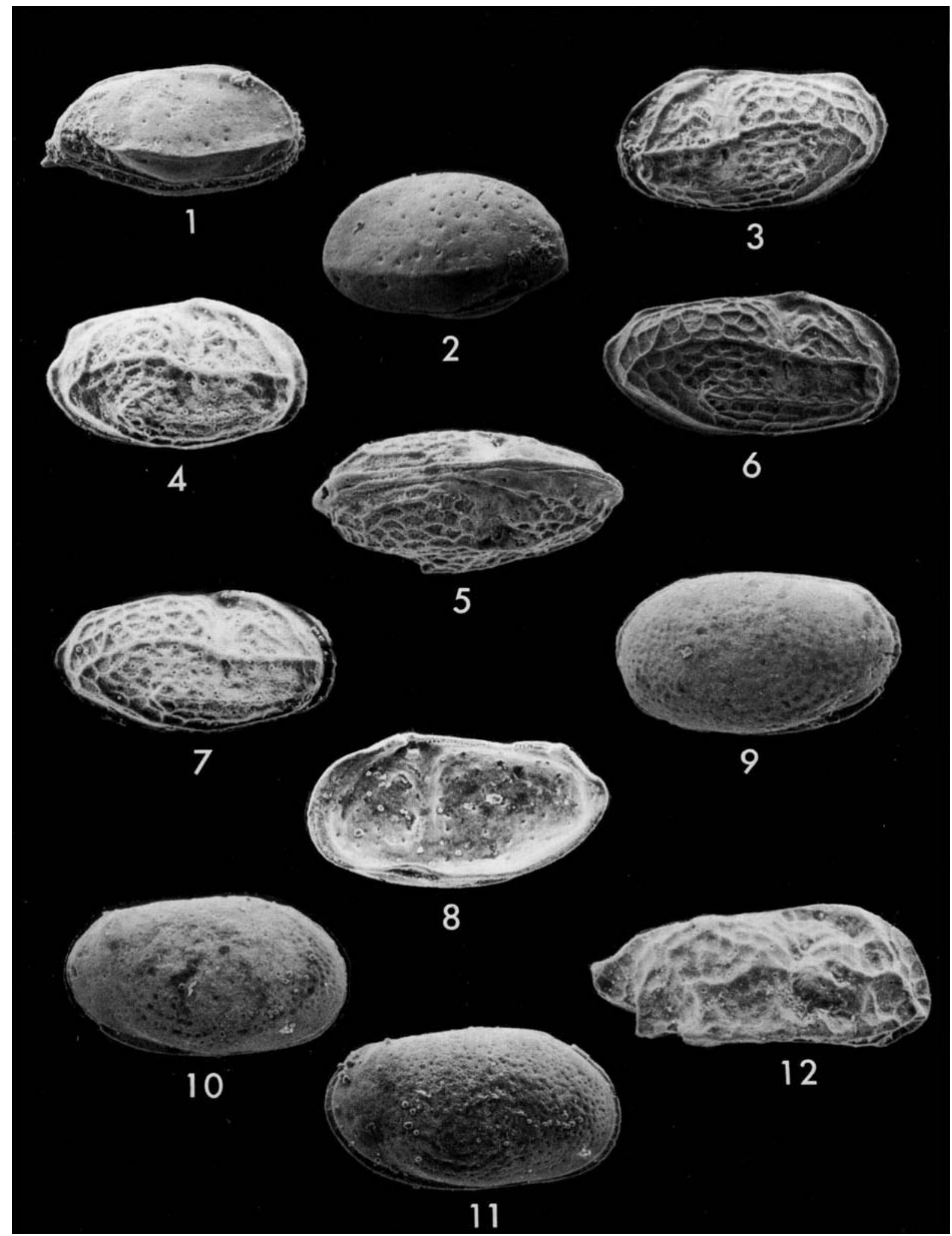


is a strong straight, horizontal median ridge which ends about one-fifth length from the posterior end. A strong ridge runs from the eye tubercle parallel to the anterior margin and about midway between the anterior and the sub-central tubercle. This rib curves round into an irregular ventral-lateral rib which ends in a rhombic tubercle again ends almost one-fifth length from the posterior marginal thickening, a rather irregular rib which runs near the anterior and roughly parallel to it and an oblique rib parallel to the posterodorsal margin and midway between that margin and the posterior termination of the median rib. The ornamentation is completed by a series of transverse ribs and intervening fossae of variable shape and size.

Dimensions of figured specimen (in $\mu \mathrm{m}$ ).

Left valve, HU.317.T.6. Length Height 933466

Remarks. Callistocythere sp. shows some similarities to Callistocythere mediterranea (Muller, 1894) figured by Doruk (1980), but the latter differs in having marginal denticulations and different surface ornamentation.

Occurrence. $2 \mathrm{~km}$ north of Qabilat ash Shurfah, Late Miocene, sample 3.

Family Trachyleberididae Sylvester-Bradley, 1948

Subfamily Trachyleberidinae Sylvester-Bradley, 1948 Genus Actinocythereis Puri, 1953

Actinocythereis spinosa sp. nov.

$$
\text { (Pl. 1, figs. 7-9) }
$$

Derivation of name. From its marked spines.

Diagnosis. This new species of genus Actinocythereis is characterised by its surface ornamentation of blunt spines and by reticulation in the area behind the anterior margin and in the muscle scar area.

Holotype. Left valve, HU.317.T.7; Pl. 1, fig. 7.

Paratype. Left valve, HU.317.T.8; PI. 1, figs. 8, 9 and one other left valve and one broken right valve (HU.317.T.25.)

Type locality and horizon. $2 \mathrm{~km}$ north of Qabilat ash Shurfah, Late Miocene, sample 3.

Description. Carapace elongate, subrectangular in lateral view with greatest height at the anterior cardinal angle. Dorsal margin straight, partially obscured by the projecting tubercles. Ventral margin straight, rising slightly posteriorly. Anterior margin broadly rounded with double row of small spines of which the inner series consists of about fourteen tubercles regularly spaced over the anterior marginal rim. The outer series consists of a combination of small nodes and fine denticles which continues along the ventral margin. The posterior margin is subtriangular, slightly pointed in the middle and decorated with small spines. The lateral surface is covered by strong blunt spines and by reticulation in the area behind the anterior margin and in the muscle scar area. Fine nodes occur scattered over the surface, some of them tending to form a longitudin- al row over the ventral margin. Eye tubercle is very marked. The muscle scar pattern is clear and consists of vertical row of four adductor scars with U-shaped frontal scar in a pit. The hinge is typical of the genus. Sexual dimorphism was not observed.

Dimensions of figured specimens (in $\mu \mathrm{m}$ ).

$\begin{array}{llll}\text { Holotype, left valve, HU.317.T.7. } & 830 & 384 \\ \text { Paratype, left valve, HU.317.T.8. } & 825 & 380\end{array}$

Remarks. This new species of Actinocythereis compares closely with Actinocythereis libyaensis El-Waer (in press). A. spinosa differs in having strong blunt spines on the lateral surface and the area behind the anterior margin covered by reticulations. In addition, it has some similarities to Actinocythereis ramaniaensis Khosla \& Pant (1981), but the latter species differs in lacking ventral marginal spines and is not reticulate in the area behind the anterior margin.

Occurrence. Only at the type locality: sample 3 of the section $2 \mathrm{~km}$ north of Qabilat ash Shurfah.

$$
\begin{gathered}
\text { Genus Keijella Ruggieri, } 1967 \\
\text { Keijella africana sp. nov. } \\
\text { (Pl. 1, figs. 10-11) }
\end{gathered}
$$

Derivation of name. From its occurrence in north Africa.

Diagnosis. The lateral surface is ornamented by slit-like pits which are distributed longitudinally in the muscle area.

Holotype. Male carapace, HU.317.T.10; Pl. 1, fig. 11. Paratype. Female carapace, HU.317.T.9; Pl. 1, fig. 10. Other material. Three carapaces (HU.317.T.26.) from samples $1 \mathrm{~b}$ and 2 .

Type locality and horizon. $2 \mathrm{~km}$ north of Qabilat ash Shurfah, Late Miocene, sample 3.

Description. Carapace ovate in lateral view, with greatest height at the anterior cardinal angle. Ventral margin straight, curving upwards at the posterior end. Dorsal margin straight but sloping gently posteriorly in the posterior third of its length. Anterior margin symmetrically rounded, decorated by 12 denticles which all lie below two-thirds height. Posterior margin subtriangular, smooth in the upper part and decorated with one pointed spine in the lower part. The lateral surface is ornamented by slit-like pits which are distributed longitudinally in the muscle scar area. The ventral longitudinal slits run from the posterior margin backwards in the posteroventral area. Another series run in a single line just behind the posterior margin. Sexual dimorphism is pronounced, the males being elongate and narrower than the females. No internal details were seen as no single valves were obtained. Dimensions of figured specimens (in $\mu \mathrm{m}$ ).

Length Height

Paratype, female carapace, HU.317.T.9. $706 \quad 373$ Holotype, male carapace, HU.317.T.10. $733 \quad 346$ 
Remarks. The present species has some similarities to Keijella hodgii (Brady, 1866) as figured by Ruggieri (1967), Doruk (1973) and El-Waer (in press), but the latter differs in that the anterior series of pits run in a single line just behind the anterior margin and the males are less high. K. africana is also somewhat similar to Keijella clauda Doruk, 1973, but the latter differs in lacking the pits on the lateral surface and the sloping dorsal margin.

Occurrence. In samples $1 \mathrm{~b}, 2$ and 3 of the section $2 \mathrm{~km}$ north of Qabilat ash Shurfah.

Genus Carinovalva Sissingh, 1973

Carinovalva carinata (Moyes, 1965)

(Pl. 1, fig. 12; Pl. 2, figs. 1-2)

1965 Ruggieria carinata n. sp. Moyes; 91-93, pl. XI, figs. $10-12$.

1969 Ruggieria (Keija) carinata carinata (Moyes); Carbonnel; 128-129, pl. 16, figs. 5-8.

1985 Carinovalva carinata (Moyes); Carbonel; pl. 95, figs. 6,7 .

Material. Five carapaces.

Dimensions of figured specimens (in $\mu \mathrm{m}$ ).

Male carapace, HU.317.T.11.

Length Height

Male carapace, HU.317.T.12.

511244

$517 \quad 250$

$\begin{array}{lrr}\text { Female carapace, HU.317.T.13. } & 482 & 282 \\ \text { Remarks. Carinovalva carinata (Moyes, } & 1965 \text { ) } & \text { was }\end{array}$

originally described from the Upper Miocene of the Bay of Biscay and recorded by Carbonnel (1969) from the Rhone Basin. The species is recorded also from the Upper Miocene (Tortonian) of Portugal by Nascimento (1983).

Occurrence. $2 \mathrm{~km}$ north of Qabilat ash Shurfah, Late Miocene, samples $1 \mathrm{~b}$ and 3 .

Family Cytheridae Baird, 1850

Subfamily Cytherinae Baird, 1850

Tribe: Paijenborchellini Deroo, 1960

Genus Neomonceratina Kingma, 1948

Neomonoceratina miocaenica sp. nov.

$$
\text { (Pl. 2, figs. 3-8) }
$$

Derivation of name. From its stratigraphic occurrence in the Miocene.

Diagnosis. A species of Neomonoceratina characterised by its coarsely punctate to reticulate surface and deep. subcentral vertical sulcus.

Holotype. Female left valve, HU.317.T.14; PI. 2, fig. 3. Paratypes. Five specimens, HU.317.T.15-19; Pl. 2, figs. 4-8 and 11 right valves, 12 left valves and five carapaces (HU.317.T.27).

Type locality and horizon. $2 \mathrm{~km}$ north of Qabilat ash Shurfah, Late Miocene, sample 3.

Description. Carapace subrectangular to subrhomboidal in lateral view, with greatest height at the anterior cardinal angle. Anterior margin broadly and obliquely rounded. Ventral margin fairly straight, slightly convex in the middle, curving upwards posteriorly. Lateral surface with a vertical sulcus which is widest dorsally and dies out above the ventral lateral ridge. The lateral surface is characterised by ridges. The ventrolateral ridge runs parallel to the ventral margin, is slightly alate posteriorly and joins the ventral rib anteriorly. The posterodorsal ridge commences behind the sulcus at above one-third height below the dorsal margin, curves upwards posterodorsally and ends behind the posterior cardinal angle. The median ridge starts from the middle of the ridge parallel to the anterior margin, runs across the median sulcus, and continues to join the inner posterodorsal rib posteriorly. The ventral rib originates from the anterior end of the median ridge, curves down parallel to the ventral margin to the posteroventral corner where it runs into the posterior rib. A small eye tubercle is present. The muscle scar pattern and the hinge are typical of the genus. Sexual dimorphism is marked, the presumed males being more elongate and narrower than the females.

Dimensions of figured specimens (in $\mu \mathrm{m}$ ).

Holotype, female left valve,

HU.317.T.14.

Length Height

Paratype, female right valve,

HU.317.T.15.

$650 \quad 370$

Paratype, male carapace,

HU.317.T.16.

Paratype, male right valve,

HU.317.T.17.

$570 \quad 335$

Paratype, male right valve,

HU.317.T.18.

680

300

660

300

Paratype, male, HU.317.T.19.

$700 \quad 350$

$660 \quad 320$

Remarks. The new species is closely comparable with Neomonoceratina delicata Ishizaki \& Kato, 1976, but the latter has a more smoothly rounded anterior margin and posteroventral spines. $N$. miocaenica is also distinguished from $N$. delicata by its more reticulate surface.

Occurrence. Only at the type locality: sample 3 of the section $2 \mathrm{~km}$ north of Qabilat ash Shurfah.

Family Loxoconchidae Sars, 1925

Genus Loxoconcha Sars, 1866

Loxoconcha sp.

(Pl. 2, figs. 9-11)

Material. Five carapaces.

Description. Carapace elongate to subovate in lateral view with greatest height at one-third the length. Anterior margin obliquely rounded, posterior margin more narrowly slightly rounded. Dorsal margin nearly straight, sloping gently backwards posteriorly. Ventral margin straight, curved upwards posteriorly. The lateral surface is finely pitted, the pits being arranged in a 
concentric pattern around the margins. Sexual dimorphism present, the presumed males being more elongate than the females. No internal details were seen as no single valves were obtained.

Dimensions of figured specimens (in $\mu \mathrm{m}$ )

Female carapace, HU.317.T.20. $\quad 586 \quad 333$

Female carapace, HU.317.T.21. $\quad 600 \quad 333$

Male carapace, HU.317.T.22. $625 \quad 326$

Remarks. The present species is compared with Loxoconcha punctatella (Reuss, 1850) as figured by Oertli (1956) and El-Waer (in press); the latter differs in having the ventral margin slightly concave in the middle and narrower posterior end.

Occurrence. $2 \mathrm{~km}$ north of Qabilat ash Shurfah, Late Miocene, sample 3.

Family Paracytherideidea Puri, 1957

Genus Paracytheridea Muller, 1894

Paracytheridea inscita Doruk, 1980

(Pl. 2, fig. 12)

1980 Paracytheridea inscita Doruk: 7(25), 143-146.

Material. One right valve.

Dimensions of figured specimens (in $\mu \mathrm{m}$ ).

Male right valve, HU.317.T.23.

Length Height $536 \quad 273$

Remarks. Paracytheridea inscita Doruk was originally described from the Upper Miocene, Antakya region of Turkey.

Occurrence. $2 \mathrm{~km}$ north of Qabilat ash Shurfah, Late Miocene, sample 3.

\section{ACKNOWLEDGEMENTS}

The author is deeply indebted to Prof. J. W. Neale of the Geology Department, Hull University, for his critical reading of the manuscript and constructive comments and suggestions. The author is also most grateful to the University of A1-Fateh, Tripoli, Libya, for financial support, the University of Hull, England, for providing the facilities for this work, and Mr. K. Sherif of IRC, Tripoli, Libya, who collected the samples.

\section{Manuscript received July 1987}

Revised manuscript accepted December 1987

\section{REFERENCES}

Carbonel, P. 1985. Néogène. In Oertli, H. J. (Ed.), Atlas des Ostracodes de France. Bull. Cent. Rech. Pau, Mem. 9, 313-335.

Carbonnel, G. 1969. Les Ostracodes du Miocene Rhodanien. Systématique, biostratigraphie écologique, paléobiologie. Docums Lab. Géol. Fac. Sci. Lyon, 32 (1-2), 469 pp.

Doruk, N. 1973a. On Keijella hodgii (Brady) 1866. StereoAtlas of Ostracod Shells, 1 (1), 53-56.

Doruk, N. 1973b. On Keijella claude Doruk. Stereo-Atlas of Ostracod Shells, 1 (1), 61-64.

Doruk, N. 1980a. On Callistocythere mediterranea (Muller). Stereo-Atlas of Ostracod Shells, 7 (23), 135-138.

Dourk, N. 1980b. On Paracytheridea inscita Doruk. StereoAtlas of Ostracod Shells, 7 (25), 143-146.

El-Waer, A. A. (In press). Miocene Ostracoda from the Al Khums Formation, NW Libya. In Proc. of the 3rd Symposium on the Geology of Libya. 1987 Tripoli. Libya.

Innocenti, F. \& Pertusati, P. 1984. Geological Map of Libya, 1:250,000. Sheet Aquylah (NH34-5), Explanatory Booklet. Industrial Research Centre, 105 pp., Tripoli, Libya.

Ishizaki, K. \& Kato, M. 1976. Neomonoceratina delicata Ishisaki \& Kato, In Ellis \& Messina (Eds.), Catalogue of Ostracoda, supplement, no. 26 (1980).

Khosla, S. C. \& Pant, P. C. 1981. Ostracoda genus Actinocythereis from Eocene and Oligocene beds of Kutch. Proc. IX Indian Coll. Strat., 156-166.

Moyes, J. 1965. Les Ostracodes du Miocène aquitain. Essai de paléoécologie stratigraphique et de paléogéographie. Drouilled, Bordeaux, $339 \mathrm{pp}$.

Nascimento, A. 1983. The Ostracoda fauna of the Portuguese Neogene and its relationship to those from the Atlantic and Mediterranean Basins. In Maddocks, R. F. (Ed.), Applications of Ostracoda Univ. Houston Geosc., 429-436.

Oertli, H. J. 1956. Ostracoden aus der Oligożanen und Miozänen Molasse der Schweiz. Abh.schweiz. paläont. Ges., 74, 119 pp.

Ruggieri. G. 1967. Due ostracofaune del Miocene alloctono della Val Marecchia (Appennino settentrionale). Riv. Ital. Paleont., 73 (1), 351-384.

Sissingh. W. 1972. Late Cenozoic of the south Aegean Island Arc. Bull. Utrecht Micropaleont., 6, 187 pp. 